\title{
METHODS AND FORM OF EDUCATION DESIGN IN THE PRESCHOOL EDUCATION SYSTEM
}

\author{
Zuparova Dilnoza Dadakhanovna \\ Yuldasheva Nodira Dadakhanovna
}

Article DOI: https://doi.org/10.36713/epra5426

\begin{abstract}
-
This thesis highlights the relevance of methods, shapes and implementation tools of design education as an innovation and effective method of modernization of nursery education. Highlights the essence of concepts of design, design education and instructional design.
\end{abstract}

KEY WORDS: design, design education, pedagogical design, project culture, competence, preschool pedagogy.

\section{INTRODUCTION}

Design is rightfully recognized as contemporary and versatile art. Modern design - a special kind of artistic activities aimed at the organization of the objective world of human space on the basis of generally accepted laws of purposeful beauty. At the same time, purposefulness means not only functionality, exact correspondence of the product to its purpose, but also harmony as a harmonious unit of spatial form, content, function and location of the design object.

In dictionary terms of design, "design" - is an English word meaning "project", "image", "thought", "idea", "unusual activity", "composite art", "artwork".

\section{TYPES OF DESIGN}

Industrial design, environmental design, graphic design, web design, process design, intelligent design. In today's developed society there is not a single profession, field of activity and service, where brilliant fantasies, creative ideas and projects of designers have not penetrated.

\section{DESIGN AREAS}

Buildings, interiors, bridges, transport, clothing, shoes, toys; books, magazines, advertising banners, company brands, logos, marketing, sales, souvenirs, food, packaging; Equipment, presentations, weddings and celebrations, show business, theater, scenography, politics, education; Software products, ideas, patents, design developments, digital technologies, the Internet, web processes.Especially in modern pedagogic purposeful, effective and proper use of design, design elements, and signals of instruments methods contributes to the quality of education, upgrading. This is because modern design is recognized as a powerful method of influencing people's minds and controlling their choices.Design prepares the child for emotions and actions, scope and ideas, moral education, interests and beliefs, aesthetic tastes, career choices, design culture, the formation of a worldview and modern technological life, teaches to make discoveries, correctly designs each life activity, as well as his own. allows you to bring your ideas to life.If a person from childhood did not have a strong ideological position and moral leadership, if he does not have aesthetic taste, if he is unsure of his thoughts and assessments, if he is unstable in his interests and beliefs, he easily accepts design signals as a guide to the "blind" actions: where to look, what needs to be achieved, who to trust and follow, who to turn to, follow the ideas hidden in design signals, about how to build life and relationships with the outside world.

The consequences of the negative impact of design signals on the mind of a preschooler are as follows: the child's desire for bright, unhealthy food; Formation of an unhealthy lifestyle; Addiction to the virtual world; Low mobility; The child gets used to playing various mobile applications, computer games; Blind imitation of 
something or someone; Penetration of other people's ideas into the minds; The development of aggression in a child; Loss of national identity.

\section{DESIGN SIGNALS AND CATEGORIES}

Shape, color, structure, texture, light, lines, animation, sound, sound, composition, beautiful expressions and texts, software products, advertising and marketing, taste, taste, Internet and web design, etc. ...

\section{DESIGN EDUCATION}

A type of training aimed at educating a person with project competence. Design education is a systematic form of organizing a creative cultural environment in a particular institution, state and society. The importance of educational design in modern education is to instill in every child the ability to competently use the world of things. For this, technological knowledge alone is not enough; it is necessary from an early age to teach children to read the artistic language of services and objects, to feel the harmony of their forms. Children must not only understand and preserve the beauty created before them, but also learn to change the world according to the laws of beauty, making it environmentally friendly, comfortable and humane. This change starts with simple things (choosing clothes and toys) and changes over time and develops in the process of human understanding of the world. The child understands not only the value, but also the essence of things and objects. Striving for a common natural unity. This serves as comfort and protection for life.

EDUCATIONAL DESIGN PEDAGOGICAL DESIGN - or instructional design. In foreign countries, this term is called "instructional design" "instructional design".

Teaching design relates to the efforts to develop the educational process, which is carried out in order to achieve clear pedagogical results. This term is widely used in the field of foreign theoretical and practical education. Pedagogical design can be understood as a process, as a field of science and research.

Design education - is much needed for children set of skills (competence in the field of design culture, such as the aesthetic taste, creativity, design culture, right thought (logic), patience, proper organization and time management, the search for optimal solutions, care, self-confidence develops qualities.The next jurisdiction may be formed by the design formation and instructional design elements in accordance with the state program "Ilk Kadam":

1. The general important competencies of the child are communicative competence, play competence, social competence, and cognitive competence.

2. Competencies in the field of child development - Competence in the field of "Physical development and the formation of a healthy lifestyle", Competence in the field of "Social and emotional development", Competence in the field of "Speech, communication, reading and writing skills", Competence in the field of "Development cognitive processes "development" competence.

In the area of preschool education reveals the following forms:

1. In the organization of preschool education and educational environment (pedagogical design, graphic design industry or object design, didactic design, web design, process design, intellectual design).

2. The design of the environment surrounding the child (architectural design, interior design, landscape design).

\section{THE PROCESS OF TEACHING DESIGN}

When a child draws, when he is engaged in slave labor, when choosing a form of color, in the process of arrangement, when a child is exposed to the environment, as a result of classes in five development centers, under the influence of group corners, communication with nature, food, clothes, health and hygiene, life protection, family and community cooperation, social partnership.

Design education and design training can use the following tools as a method of forming a children's design culture: family and partnership with preschool educational institutions; cooperation with other levels of continuing education; cooperation with local communities and public organizations; social partnership; special trainings for specialists and parents, open days; master classes, trainings, exhibitions for children, conducted by famous designers, artists and craftsmen; exhibitions and competitions of children's design creations; Media involvement; Distance and online education;Demonstration of media products dedicated to children's design,

In short, today, in a situation where it is necessary to identify, develop and apply innovative methods and tools for modernizing education in the process of preschool education and training, it is obvious that design and design education is an innovative method. This is confirmed by the experience of developed countries. An indepth study of the design and design of education, elements of pedagogical design will help develop and apply a new innovative method that will give highly effective results in modernizing the preschool pedagogical process. 


\section{REFERENCE}

1. "Мактабгача таълим ва тарбия тугхрисида"ги 2019 йил 17 декабрьда қабул килинган 595 сонли ЎРК.

2. Цай Е.Ф., Грошева И.В., Назарова В.А., Исмаилова М.А.. Пособие для тренеров «Внедрение Государственной учебной программы «Илккадам»для дошкольных образовательных учреждений $и$ Государственных требований к развитию детей раннего и дошкольного возраста Республики Узбекистан» Ташкент, 2019 г.

3. Конышева, Н. М. Теоретические основы дидактической системы дизайнерского образования младших школьников [Текст]: автореф. дис. ... д-ра пед. наук / Н. М. Конышева. - М., 2000.

4. Ткаченко, Е. В. Концепция непрерывного дизайн-образования [Текст] / Е. В. Ткаченко, С. М. Кожуховская. - М.: Изд. иентр НОУ «ИСОМ». 2006. 